\section{Mercantilização do ensino superior e o Serviço Social brasileiro}

The commercialization of the Brazilian university education and Social Services

\section{Francine Helfreich Coutinho dos Santos*}

A dinâmica da mundialização do capital, que desencadeou significativas alterações no processo de reestruturação produtiva, impôs ao cenário político dos países periféricos uma série de modificações na condução da política educacional, sobretudo no que diz respeito à expansão do ensino superior.

Brasil e a América Latina, peculiaridades à parte, apresentam formas diferenciadas de expansão do ensino superior: de um lado, temos as iniciativas que ampliam o papel do mercado na comercialização da educação no setor de serviços; de outro temos à venda serviços que até então eram de prerrogativa exclusiva do Estado, mas que são desregulamentados via estabelecimento de contratos de serviços públicos

* Bacharel em Serviço Social pela Universidade Federal Fluminense (2000), mestre em Serviço Social pela UFRJ (2006), doutoranda em Serviço Social pela Uerj, membro do Centro de Estudos Otávio Ianni da Uerj, professora da Escola de Serviço Social da Universidade Federal Fluminense - Niterói/RJ, Brasil. E-mail: francinesantos@yahoo.com.br. por instituições privadas, por meio das fundações, contratos e convênios com o setor empresarial que mercantilizam e privatizam internamente as universidades públicas brasileiras.

A obra de Larissa Dahmer Pereira - Educação e Serviço Social: do confessionalismo ao empresariamento da formação profissional — oferece uma das primeiras e mais completas análises sobre a relação entre a política educacional e a formação do assistente social no Brasil.

Foi recorrendo às obras de Marx que os pressupostos teórico-metodológicos de suas análises foram definidos: a historicidade, a totalidade e a dialética. Tais categorias possibilitaram reiterar as convicções da autora sobre o modo de produção capitalista, sistema este capaz de criar uma exacerbante miséria de massa, em contraste com a opulência de poucos. Com uma crítica radical e precisa sobre as determinações do capital para a educação superior, Pereira realiza uma profunda análise sobre a realidade do Serviço Social brasileiro e o viés privatista que ilumina a organização dos cursos de Serviço Social, sobretudo a partir de 1990, sob o aval dos governos da época. O estudo realizado traz elementos relevantes para a compreensão da trajetória da formação profissional do assistente social, que tem sua gênese marcada pelo caráter confessional das primeiras Escolas de Serviço Social, impressa pela lógica caritativa, mas que, atualmente, pode ser enxergado como mais um "serviço" promissor a ser comercializado. 
Nesta perspectiva, a hipótese de Pereira é que entre 1930 e 2002 - período definido para sua pesquisa - a abertura de Escolas de Serviço Social (ESS) acompanha o movimento mais amplo da política educacional brasileira, articulado com as relações entre classes sociais e o Estado e a própria posição do Brasil na divisão internacional do trabalho.

A obra é dividida em quatro partes. $\mathrm{Na}$ primeira, com o título "Capitalismo, luta de classes e educação: de direito social a "serviço", tem-se um retrato dos avanços e recuos das políticas sociais sob a égide da crise estrutural do capital no pós-1970, em que se percebe a mutação da educação — enquanto política social — da esfera do direito para a órbita dos serviços, sobretudo nos países periféricos.

Em "Educação superior no Brasil e Serviço Social", a particularidade da política educacional do país é recuperada, enfatizando-se o desenvolvimento do ensino superior vinculando à origem das primeiras Escolas de Serviço Social. O recorte temporal nesse capítulo é o período entre 1930 e 1963.

$\mathrm{O}$ capítulo posterior, intitulado "Modernização conservadora, ensino superior e Serviço Social", trata do período subsequente, abordando a expansão das Instituições de Ensino Superior (IES) no contexto da inserção definitiva do país, de forma subalternizada e periférica no processo de internacionalização do capital monopolista. Observa a autora que nos anos de chumbo a profissão e a formação passam por um amplo processo de revisão, questionamen- to e autocrítica, rompendo com o histórico conservadorismo basilar da área.

Fugindo dos moldes tradicionais de escrita, o livro de Pereira não se finda com uma conclusão. No seu último capítulo - "Mercantilização do ensino superior brasileiro e a 'exploração' privatista das Escolas de Serviço Social na década de 1990", a autora se debruça sobre o elemento mais inovador em sua obra: a interpretação sobre a ampliação das Escolas de Serviço Social. A pesquisa mostra em números o exorbitante crescimento de cursos de Serviço Social, caracterizados quanto a sua organização acadêmica (universidade, centros universitários etc.), quanto à categoria administrativa (comunitárias, confessionais, filantrópicas) e quanto à natureza jurídica de suas mantenedoras: públicas ou privadas. O projeto societário que repercute na privatização do ensino superior é gestado no final da década de 1980, se materializa no Brasil após as eleições presidenciais ocorridas em 1989, quando diversas iniciativas na gestão de Fernando Collor de Melo foram manifestadas no sentido de reformulação do ensino superior sob a égide mercantil. Entretanto, foi especialmente na gestão de Fernando Henrique Cardoso (FHC) que este processo se acirrou. Para tanto, foram utilizadas inúmeras estratégias, sobretudo os pressupostos ideopolíticos da Terceira Via: a despolitização das classes e a repolitização da sociedade civil sobre a lógica da solidariedade entre classes, a responsabilidade social, a crítica ao socialismo, a recuperação do individualismo enquanto valor positivo e também a necessidade de 
um Estado que não precisa ser grande, mas forte para gerar na sociedade civil uma postura proativa, sendo este um espaço de colaboração e solidariedade entre as classes. Assim, a veiculação desses pressupostos via educação é fundamental para o projeto do grande capital. Na última década do século anterior, presencia-se no ensino público superior um verdadeiro sucateamento por meios de mecanismos legais que incentivaram, consequentemente, a ampliação do ensino privado. Esses elementos não sincronizados caracterizaram a política educacional do ensino superior do período: 1) a redução progressiva do montante de recursos para a universidade; 2) as aposentadorias forçadas de docentes, devido às perdas de diretos oriundas da Reforma Previdenciária de 1998; 3) a não realização de concursos públicos durante os dois mandatos de FHC, forçando a realização de inúmeros contratos de professores substitutos; 4) congelamento salarial durante oito anos do governo FHC e institucionalização da Gratificação de Estímulo ao Trabalho Docente (GED); 5) privatização interna das universidades por meio das fundações; e 6) limitação da autonomia universitária, entre outros.

Este processo não excluiu o Serviço Social. A pesquisa mostra que entre 1995 e 2002 foram criados mais de 49 cursos de Serviço Social. Atrelados a esse fenômeno, a diversificação das instituições de ensino possibilitou a proliferação de cursos de pouco custo em instituições de ensino superior que legalmente não são obrigadas a realizar pesquisas. Segundo a autora este processo arrebatador de crescimento de unidades de ensino, sobretudo privado, aparece como a real laicização e empresariamento do ensino de Serviço Social, articulado com o movimento do Estado brasileiro de incentivo à expansão do ensino superior, via setor privado e não confessional.

Coadunado com as necessidades do espraiamento da lógica mercantil, o capital se realiza também com a formação de uma intelectualidade difusora da ideologia colaboracionista e consensual que conforma uma sociabilidade burguesa. Tal processo se materializa nos cursos de baixa qualidade, nas salas de aulas superlotadas, com professores mal remunerados, comprometendo o exercício da docência, dada a condição de mercadoria que a educação superior assume. Pereira mostra ainda que entre 2003 e 2006 foram criados 129 novos cursos, $94 \%$ deles de natureza privada. E essa orquestração de elementos possibilita uma valiosa análise prospectiva da profissão:

No âmbito do Serviço Social, infere-se que, em pouco menos de uma década, o perfil dos assistentes sociais brasileiros estará completamente transformado. A tendência deste perfil não é nada animadora, pois estará baseada em uma formação profissional a distância, aligeirada, mercantilizada e, portanto, com poucas chances de concretizar o perfil de um profissional crítico e competente teórica, técnica, ética e politicamente, delineado pela Abepss em 1996. (Pereira, 2008, p. 194)

Finalizando, esta obra apresenta, além do exame claro e crítico sobre a expansão 
das Escolas de Serviço Social brasileiras, inúmeras contribuições para compreender as estratégias burguesas de validação da sua hegemonia via educação. Apresenta linguagem acessível, com cuidadoso rigor teórico-metodológico. Além disto, a pesquisa se caracteriza por ser mais uma obra que contribui para as reflexões sobre os fundamentos teórico-metodológicos do Serviço Social, já que Pereira apresenta elementos importantes para a compreensão das particularidades do processo de institucionalização e legitimação do Serviço Social na sociedade brasileira, a partir dos determinantes históricos que marcam a formação profissional.

Artigo recebido em fev./2010

Aprovado em mar./2010

\section{Referência bibliográfica}

PEREIRA, Larissa Dahmer. Educação e Serviço Social: do confessionalismo ao empresariamento da formação profissional. São Paulo: Xamã, 2008. 